\title{
PENGARUH GAYA KEPEMIMPINAN TRANSFORMASIONAL KEPALA SEKOLAH DAN MOTIVASI KERJA TERHADAP DISIPLIN KERJA GURU MADRASAH ALIYAH NEGERI DI WILAYAH JAKARTA SELATAN
}

\author{
Heru Wibowo \\ Universitas Muhammadiyah Prof. Dr. HAMKA (UHAMKA) Jakarta \\ Email: heruwibowo@uhamka.ac.id
}

\begin{abstract}
This research aims to recognize the influence of the transformational school principal style leadership and working's motivation to the teachers' of senior Islamic high school state in the South Jakarta which consists of 143 people. Because of the large samples which consist of 105 people, the writer uses Slovin formula in this research and the way of data taken is based on school unit proportionally. The research variable includes the transformational school principal style leadership (X1), Working's motivation (X2) and the discipline of teachers' dedication (X3). Then the writer uses questionnaire to get the data. This research hypothesis is (1) there is a direct influence, the transformational school principal style leadership to the discipline of teachers' dedication, (2) there is a direct influence between working's motivation and the discipline of teachers' dedication, (3) there is direct influence between the transformational school principal style leadership and working's motivation. The each hypothesis $1,2,3$ are tested by simple regression and partial correlation. However, the writer uses the analysis for the next. The writer uses the survey as his method with the data analysis inferentially. The research result which is found is the first research result concludes that there is a positive influence between the transformational school principal style leadership (X1) and the discipline of teachers' dedication (X3), with the coefficient iv correlation is 0.639 , on $\alpha=0.05$, and the determination coefficient is 0.408 . It shows that $40.8 \%$ of the discipline of teachers' dedication is strengthened by the transformational school principal style leadership with coefficient channel 0.344 and correlation is 0.639 . The result of second hypothesis concludes that there is a positive influence between working motivation (X2) and the discipline of teachers' dedication (X3) with the coefficient correlation is 0.529 on $\alpha=0.05$, the determination coefficient is 0.279 . it shows that $27.9 \%$ is strengthened by the working's motivation with coefficient channel 0.529 and the correlation is 0.529 . the result of third hypothesis concludes that there is a positive influence between independent variable of the transformational school principal style leadership (X1) and working's motivation (X3) with the coefficient correlation is 0.656 the determination coefficient is 0.430 . it shows that $43.0 \%$ of the discipline of teachers' dedication is strengthened by the transformational school principal style leadership and the working teachers' motivation with coefficient channel is 0.656 and the correlation is 0.185 . This research recommends all the school
\end{abstract}


principals to improve the transformational style leadership ability in order to do their policies and to improve the teachers of Islamic senior high school state' motivation in the south Jakarta in order to create the good and discipline work.

Keywords : Leadership Style, Motivation, and Work Discipline

Abstrak: Penelitian ini bertujuan untuk mengetahui tingkat pengaruh gaya kepemimpinan transformasional kepala sekolah, motivasi kerja terhadap disiplin kerja guru MAN di Jakarta Selatan, yang seluruhnya berjumlah 143 orang. Besarnya sampel dalam penelitian ini ditetapkan dengan rumus Slovin sebanyak 105 orang dan pengambilannya didasarkan unit sekolah secara proporsional. Variabel penelitian meliputi gaya kepemimpinan transformasional kepala sekolah (X1), motivasi kerja (X2) dan disiplin kerja guru (X3) kemudian untuk mengumpulkan data menggunakan angket. Hipotesis penelitian ini adalah (1) terdapat pengaruh langsung gaya kepemimpinan transformasional kepala sekolah terhadap disiplin kerja guru, (2) terdapat pengaruh langsung motivasi kerja terhadap disiplin kerja guru, (3) terdapat pengaruh langsung gaya kepemimpinan transformasional kepala sekolah terhadap motivasi kerja guru. Hipotesis 1, 2 dan 3 tersebut masing-masing diuji dengan regresi sederhana dan korelasi parsial sedangkan untuk selanjutnya menggunakan analisis jalur. Metode yang dipakai dalam penelitian ini adalah metode survey dengan analisis data secara inferensial. Hasil penelitian yang diperoleh adalah hasil pengujian hipotesis pertama diperoleh kesimpulan bahwa terdapat pengaruh positif antara gaya kepemimpinan transformasional kepala sekolah (X1) dengan disiplin kerja guru (X3), dengan koefisien korelasi sebesar 0.639 pada $\alpha=0.05$, dan koefisien determinansi sebesar 0.408 hal ini menunjukkan bahwa $40.8 \%$ disiplin kerja guru diperkuat oleh gaya kepemimpinan transformasional kepala sekolah dengan koefisien jalur 0.344 dan korelasi sebesar 0.639. Hasil pengujian hipotesis kedua diperoleh kesimpulan bahwa terdapat hubungan positif antara motivasi kerja (X2) dengan disiplin kerja guru (X3), dengan koefisien korelasi sebesar 0.529 pada $\alpha=0.05$, dan koefisien determinansi sebesar 0.279 hal ini menunjukan bahwa $27.9 \%$ disiplin kerja guru diperkuat dengan ii motivasi kerja dengan koefisien jalur 0.529 dan korelasi sebesar 0.529. Hasil pengujian hipotesis ketiga diperoleh kesimpulan bahwa terdapat hubungan positif antara variabel bebas gaya kepemimpinan transformasional kepala sekolah (X1) dan motivasi kerja (X3) dengan koefisien korelasi sebesar 0.656 dan koefisien determinansi sebesar 0.430 menunjukan bahwa $43.0 \%$ disiplin kerja guru dapat diperkuat dengan gaya kepemimpinan transformasional kepala sekolah dan motivasi kerja guru dengan koefisien jalur 0.656 dan korelasi sebesar 0.185 . Hasil penelitian ini merekomendasikan kepada kepala sekolah untuk meningkatkan keterampilan gaya kepemimpinann transformasional dalam menjalankan tugas memimpinnya, serta 
meningkatkan motivasi kerja guru Madrasah Aliyah Negeri di wilayah Jakarta Selatan untuk mendorong terciptanya disiplin kerja yang baik.

Kata Kunci : Gaya Kepemimpinan, Motivasi, dan Disiplin Kerja 


\section{PENDAHULUAN}

Guru merupakan salah satu unsur penting dalam proses pendidikan, yang berperan bukan hanya sebagai pengajar tetapi juga sebagai pendidik, membimbing dan membina anak didik agar menjadi manusia susila yang cakap, aktif, kreatif, dan mandiri. Oleh karena itu, tugas yang berat dari seorang guru ini pada dasarnya hanya dapat dilaksanakan oleh guru yang memiliki tanggung jawab dan disiplin dalam melaksanakan tugas pokok dan fungsinya. Akan tetapi, Madrasah Aliyah, dalam naungan kementrian agama yang selama ini memunculkan image dalam masyarakat bahwa guru yang bekerja di MAN adalah guru-guru yang memiliki disiplin kerja yang rendah. Dan dalam kaitannya dengan disiplin kerja guru, gaya kepemimpinan kepala sekolah memegang peranan penting dalam pencapaian disiplin kerja, karena gaya kepemimpinan merupakan suatu proses interaksi yang terjadi setiap saat antara pemimpin dan bawahannya dalam hal mempengaruhi agar bawahannya bekerja sesuai dengan tujuan organisasi yang diharapkan. Selain itu kepala sekolah harus memantau beberapa hal yang erat kaitannya dengan kehadiran, kreativitas kerja, 3 taat pada sistem dan prosedur kerja, efektifitas kerja, tanggung jawab kerja, ketekunan kerja, sehingga berdampak pada perbaikan tingkat kedisiplinan guru. (Komarudin,112:1992)

Oleh karena itu, dalam sebuah madrasah, kepala madrasah harus memiliki tipe kepemimpinan transformasional yaitu untuk melakukan proses mempengaruhi guru dengan cara melibatkan sisi-sisi idealisme para guru sehingga akan melahirkan disiplin kerja yang baik. Dengan cara seperti ini guru akan tersentuh sisi-sisi kepribadiannya dan merasa tertantang untuk melakukan segala hal menjadi lebih baik. Misalnya kepala madrasah senantiasa mengingatkan akan visi kemudian menghubungkannya dengan sasaran tugas yang hendak dicapai, maka guru akan merasa diingatkan tugas pokoknya dalam mengajar.

Penelitian ini bertujuan untuk menunjukkan bahwa gaya kepemimpinan kepala Madrasah Aliyah Negeri (MAN) dan motivasi kerja merupakan faktor yang cukup menentukan tingkat kedisiplinan kerja guru. Kegunaan dalam penelitian ini dapat memberikan gambaran bagi dunia pendidikan dalam upaya meningkatkan disiplin kerja guru di sekolah dan dapat memperkaya studi tentang gaya kepemimpinan transformasional Kepala Sekolah dan motivasi kerja guru dalam proses pembelajaran.

\section{METODE PENELITIAN}

Penelitian ini menggunakan metode survey kausal dengan teknik korelasional yang digunakan untuk mengukur kadar pengaruh gaya kepemimpinan kepala sekolah dan motivasi kerja terhadap disiplin kerja guru. Menggunakan metode survey yaitu penelitian yang mengambil sampel satu populasi dan menggunakan kuesioner sebagai alat pengumpul data. (Masri Singarimbun dan sopian Efendi,3:1999)

Penelitian dilaksanakan di Madrasah Aliyah Negeri yang berada di Wilayah Jakarta Selatan terdiri dari 5 Sekolah yaitu MAN 4 Model Jakarta, MAN 7 Jakarta, MAN 11 Jakarta, MAN 13 Jakarta dan MAN 19 Jakarta. Penelitian ini berlangsung selama 6 (enam) bulan yaitu mulai bulan Oktober 2013 hingga Maret 2014. Sasaran populasi dalam penelitian ini adalah seluruh guru Madrasah Aliyah Negeri Jakarta Selatan yang berjumlah 143 guru. 
untuk menentukan besarnya jumlah sampel dari populasi dengan cara teknik acak sederhana atau Simple Random Sampling, cara atau tahapan sebagai berikut: 1) Mencatat seluruh MAN di wilayah Jakarta Selatan, 2) Menetapkan MAN yang akan dijadikan tempat ujicoba instrumen, maka terpilih MAN 19 Jakarta, 3) Menentukan jumlah guru untuk ujicoba instrumen sesuai dengan kaidah penelitian, maka ditetapkan sebanyak 30 orang guru, 4) Maka jumlah sampel penelitian adalah jumlah populasi 143 orang guru dan 30 orang guru sebagai uji coba penelitian, maka merujuk pada rumus Slovin, pada populasi sebanyak 143 orang guru, maka diperoleh sampel penelitian sebanyak 105 orang guru, dengan perhitungan sebagai berikut:

\begin{tabular}{|l|l|c|c|c|c|}
\hline No & Nama Madrasah & $\begin{array}{c}\text { Jumlah } \\
\text { Populasi }\end{array}$ & Jumlah Sampel & Ket & Uji Coba \\
\hline 1 & AN 7 Jakarta & 22 & 3 x 105 $=20$ & Penelitian & - \\
\hline 2 & AN 11 Jakarta & 25 & $3^{\text {x } 105=23}$ & Penelitian & - \\
\hline 3 & AN 18 Jakarta & 23 & $3^{\text {x } 105=22}$ & Penelitian & - \\
\hline 4 & AN 4 Model Jakarta & 43 & $3^{\text {x } 105=40}$ & Penelitian & - \\
\hline
\end{tabular}

Tabel 3.3. Proporsi Pengambilan Sampel dari Populasi

Untuk data penelitian ini perlu diadakan pengujian normalitas distribusi populasi berdasarkan pengolahan data. Uji keberartian dan kelinearan persamaan regresi sederhana, persamaan regresi sederhana antar variabel perlu di uji keberartian dan kelinearannya. Uji ini dilakukan dengan mengelompokkan skor antar variabel, kemudian hasil perhitungannya di masukkan dalam tabel ANAVA guna memperoleh harga F hitung.

Instrumen penelitian yang digunakan adalah angket daftar pernyataan yang diberikan kepada orang lain yang bersedia memberikan respon (responden) sesuai dengan permintaan pengguna, dengan tujuan untuk mencari informasi secara mendalam mengenai motivasi kerja guru Madrasah Aliyah Negeri Jakarta Selatan.

\section{HASIL DAN PEMBAHASAN}

Tabel 4.1. Jumlah Responden Berdasarkan Jenis Kelamin

\begin{tabular}{|l|c|c|c|}
\hline No & Jenis Kelamin & Jumlah & Prosentase \\
\hline 1. & Laki-laki & 43 & 40.9 \\
\hline 2. & Perempuan & 62 & 59.1 \\
\hline & Jumlah & 105 & 100.0 \\
\hline
\end{tabular}

Dari data pada tabel 4.1 terlihat bahwa guru-guru MAN di Jakarta Selatan lebih banyak didominasi oleh guru perempuan (59.1\%). 
Tabel 4.2. Jumlah Responden Berdasarkan Tingkat Pendidikan

\begin{tabular}{|l|rr|r|r|}
\hline No & \multicolumn{2}{|c|}{ Tingkat Pendidikan } & Jumlah & \multicolumn{2}{|c|}{ Prosentase } \\
\hline 1. & D3 & 3 & 2.80 \\
\hline 2. & S1 & 58 & 55.20 \\
\hline 3 & S2 & 44 & 42.00 \\
\hline & \multicolumn{2}{|r|}{ JUMLAH } & 105 & 100.00 \\
\hline
\end{tabular}

Sumber : Tata Usaha MAN di Jakarta Selatan 2013/2014

Dari data tabel 4.2 terlihat bahwa guru yang memiliki tingkat pendidikan S1 berjumlah 58 orang (55.20\%) artinya lebih banyak dibandingkan dengan yang berpendidikan yang lainnya.

Tabel 4.3. Jumlah Responden Berdasarkan Masa Kerja

\begin{tabular}{|l|c|c|c|}
\hline No & Masa Kerja & Jumlah & Prosentase \\
\hline 1. & $<5$ Tahun & 6 & 5.71 \\
\hline 2. & $6-10$ Tahun & 17 & 16.10 \\
\hline 3. & $11-15$ Tahun & 19 & 18.09 \\
\hline 4. & $16-20$ Tahun & 46 & 43.81 \\
\hline 5. & $>20$ Tahun & 17 & 16.19 \\
\hline \multicolumn{2}{|l|}{ Jumlah } & 105 & 100.00 \\
\hline
\end{tabular}
Sumber : Tata Usaha MAN di Jakarta Selatan 2013/2014

Dari tabel 4.3 terlihat bahwa komposisi masa kerja guru-guru MAN di Jakarta Selatan sebanyak 46 orang atau $43.81 \%$ memiliki masa kerja 16 sampai 20 tahun.

Tabel 4.4. Jumlah Responden Berdasarkan Usia

\begin{tabular}{|l|c|c|c|}
\hline No & Usia & Jumlah & Prosentase \\
\hline 1. & $25-35$ Tahun & 12 & 9.52 \\
\hline 2. & $36-45$ Tahun & 56 & 4.76 \\
\hline 3. & $>46$ Tahun & 37 & 3.17 \\
\hline \multicolumn{2}{|c|}{ Jumlah } & 105 & 100.00 \\
\hline
\end{tabular}
Sumber : Tata Usaha MAN di Jakarta Selatan 2013/2014

Dari tabel 4.5 terlihat bahwa jumlah responden yang paling banyak berusia 36 sampai 45 tahun.

Tabel 4.5. Jumlah Responden Berdasarkan Pangkat dan Golongan

\begin{tabular}{|l|c|c|c|}
\hline No & Pangkat/Golongan & Jumlah & Prosentase \\
\hline 1. & Pembina TK 1 / IVb & 2 & 1.90 \\
\hline 2. & Pembina / Iva & 48 & 45.70 \\
\hline 3. & Penata TK I / IIId & 5 & 4.65 \\
\hline 4. & Penata / IIIc & 32 & 30.45 \\
\hline 5. & Penata Muda TK I / IIIb & 12 & 11.70 \\
\hline 6. & Penata Muda / IIIa & 6 & 5.60 \\
\hline \multicolumn{2}{|c|}{ Jumlah } & 105 & 100.0 \\
\hline
\end{tabular}
Sumber : Tata Usaha MAN di Jakarta Selatan 2013/2014


Tabel 4.5 menunjukkan bahwa pangkat/golongan responden terbanyak adalah Pembina/IVa yaitu sebanyak 48 orang (45.7\%).

\section{Uji Istrumen Penelitian}

Tabel 4. 6 Rekapitulasi Hasil Uji Coba Item Pernyataan Instrumen

\begin{tabular}{|c|c|c|c|c|c|c|}
\hline \multirow[t]{2}{*}{ Kuesioner Variabel } & \multicolumn{2}{|c|}{ trumen } & \multicolumn{2}{|c|}{ Tidak Valid } & \multirow{2}{*}{\begin{tabular}{|l} 
mlah \\
alid \\
Jml \\
\end{tabular}} & or \\
\hline & $\mathrm{Jml}$ & $\%$ & $\mathrm{Jml}$ & $\%$ & & $\%$ \\
\hline $\begin{array}{l}\text { Kepemimpinan } \\
\text { Transformasional }\left(\mathrm{X}_{1}\right)\end{array}$ & & p\% & & $\%$ & & $\%$ \\
\hline Motivasi Kerja $\left(\mathrm{X}_{2}\right)$ & & p\% & & $\%$ & & $\%$ \\
\hline Disiplin Kerja $\left(\mathrm{X}_{3}\right)$ & & p\% & & $\%$ & & $\%$ \\
\hline Jumlah & 6 & p\% & & & & $\%$ \\
\hline
\end{tabular}

Berdasarkan data tabel di atas, ternyata item pernyataan yang valid merupakan item yang terpilih dan dapat digunakan sebagai alat pengumpul data (kuesioner).

\section{Uji Reliabilitas}

Tabel 4.7. Hasil Uji Reliabilita

\begin{tabular}{|c|c|c|}
\hline Variabel & Reliabilitas & Kriteria \\
\hline Kepemimpinan Transformasional $\left(\mathrm{X}_{1}\right)$ & 0.865 & liabilitas Tinggi \\
\hline Motivasi Kerja $\left(\mathrm{X}_{2}\right)$ & 0.839 & liabilitas Tinggi \\
\hline Disiplin Kerja $\left(\mathrm{X}_{3}\right)$ & 0.753 & liabilitas Tinggi \\
\hline
\end{tabular}

Sumber : Lampiran uji validitas reliabilitas

Dari data di atas variabel kepemimpinan kepala sekolah (X1) adalah 0.865 dengan kriteria reliabilitas tinggi, variabel motivasi kerja (X2) adalah 0.839 dengan kriteria reliabilitas tinggi dan variabel disiplin kerja (X3) adalah 0.753 dengan kriteria reliabilitas tinggi.

\section{Deskripsi Data}

Data penelitian ditampilkan berdasarkan deskripsi data ketiga variabel, yaitu: (1) gaya kepemimpinan transformasional (X1), (2) Motivasi kerja guru (X2), dan (3) Disiplin kerja guru (X3).

Berikut ini disajikan jumlah data, mean, median, modus, range, nilai maksimum, nilai minimum, dan standar deviasi dari masing-masing kelompok data hasil penelitian, yaitu: 
Tabel 4.8. Deskriptif Data Penelitian Statistics

\begin{tabular}{|c|c|c|c|c|}
\hline & & $\begin{array}{c}\text { Gaya Kepemimpinan } \\
\text { Transformasional }\end{array}$ & $\begin{array}{c}\text { Motivasi } \\
\text { Kerja }\end{array}$ & $\begin{array}{l}\text { Disiplin } \\
\text { Kerja }\end{array}$ \\
\hline \multirow[t]{2}{*}{$\mathrm{N}$} & Valid & 105 & 105 & 105 \\
\hline & Missing & 이 & 0 & 0 \\
\hline \multicolumn{2}{|c|}{ Mean } & 1.0894 & 1.1656 & 1.0434 \\
\hline \multicolumn{2}{|c|}{ Median } & 1.0900 & 1.1600 & 1.0200 \\
\hline \multicolumn{2}{|c|}{ Mode } & 110.00 & 115.00 & 102.00 \\
\hline \multicolumn{2}{|c|}{ Std. Deviation } & 6.10931 & 5.95484 & 8.49981 \\
\hline \multicolumn{2}{|c|}{ Variance } & 37.324 & 35.460 & 72.247 \\
\hline \multicolumn{2}{|c|}{ Range } & 28.00 & 33.00 & 39.00 \\
\hline \multicolumn{2}{|c|}{ Minimum } & 98.00 & 99.00 & 90.00 \\
\hline \multicolumn{2}{|c|}{ Maximum } & 126.00 & 132.00 & 129.00 \\
\hline \multicolumn{2}{|c|}{ Sum } & 1.14 & 1.22 & 1.10 \\
\hline
\end{tabular}

\section{Distribusi Frekuensi Variabel gaya kepemimpinan transformasional (X1)}

Berdasarkan hasil perhitungan terhadap variabel gaya kepemimpinan transformasional diperoleh skor minimum 98 dan skor maksimum 126 dengan demikian rentang skor sebesar 28. Angka-angka ini kemudian di analisis hasilnya adalah sebagai berikut: rata-rata (mean) adalah 108, median adalah 109, modus adalah 110 dan standar deviasi 6.10, banyaknya kelas adalah 8, dan interval kelas adalah 5. Distribusi frekuensi variabel gaya kepemimpinan kepala sekolah, disajikan pada tabel dan grafik histogram, sebagai berikut:

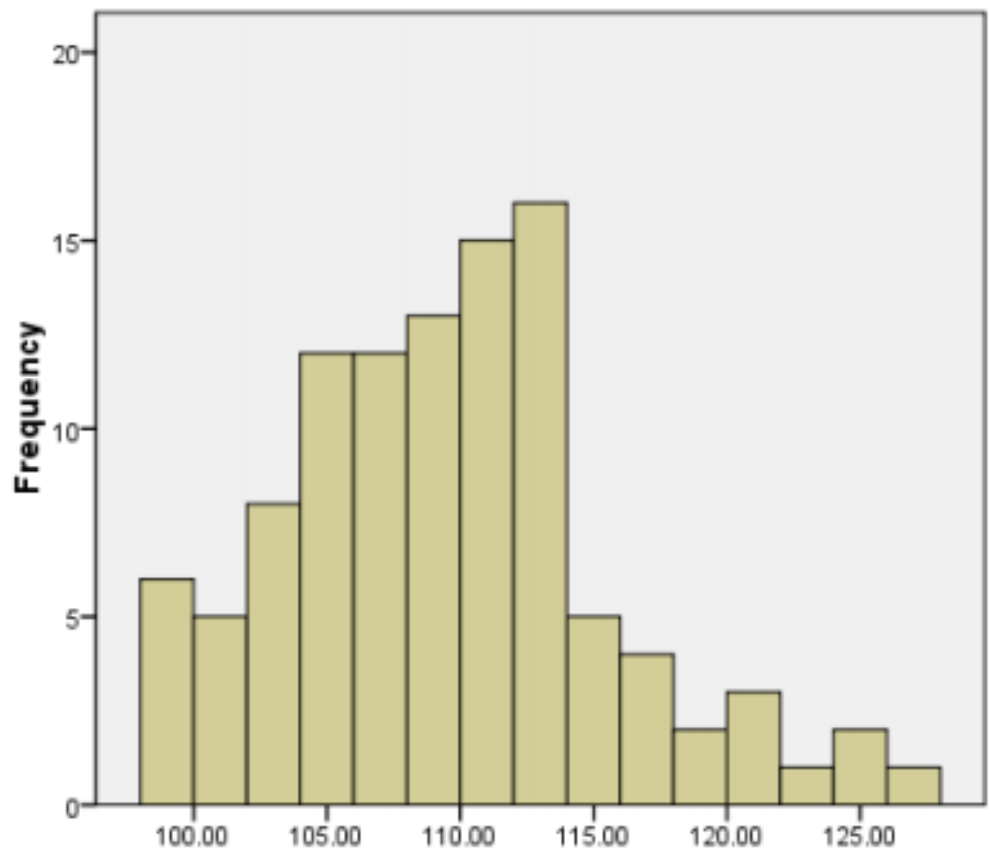

Mean $=108.94$ Std. Dev. $=6.10$ $\mathrm{N}=105$

Gambar 4.1. Histogram Distribusi gaya kepemimpinan kepala sekolah (X1) 


\section{Distribusi Frekuensi Variabel motivasi kerja guru (X2)}

Tabel 4.10. Distribusi frekuensi motivasi kerja guru (X2)

\begin{tabular}{|c|c|c|c|c|}
\hline \multirow{2}{*}{ No } & Interval Kelas & \multicolumn{3}{|c|}{ Frekuensi } \\
\cline { 3 - 5 } & & Absolut & Relatif (\%) & Kumulatif (\%) \\
\hline 1 & $99-103$ & 2 & 1.91 & 1.91 \\
\hline 2 & $104-108$ & 6 & 5.71 & 7.62 \\
\hline 3 & $109-113$ & 18 & 17.14 & 24.76 \\
\hline 4 & $114-118$ & 46 & 43.81 & 68.56 \\
\hline 5 & $119-123$ & 22 & 20.95 & 89.52 \\
\hline 6 & $124-128$ & 7 & 6.67 & 96.19 \\
\hline 7 & $129-133$ & 4 & 3.81 & 100.00 \\
\hline \multicolumn{2}{|c|}{ Jumlah Total } & 105 & 100.00 & \\
\hline
\end{tabular}

\section{Distribusi Frekuensi Variabel Disiplin kerja guru (X3)}

Berdasarkan hasil perhitungan terhadap variabel disiplin kerja guru diperoleh skor minimum 83 dan skor maksimum 122, dengan demikian rentang 98 skor sebesar 39. Angka-angka ini kemudian di analisis hasilnya adalah sebagai berikut: rata-rata (mean) adalah 104.2, median adalah 105, modus adalah 97, standar deviasi 8.4. Banyaknya kelas adalah 7 dan interval kelas adalah 6 . Distribusi frekuensi variabel disiplin kerja, disajikan pada tabel dan grafik histogram, sebagai berikut :

Tabel 4.11. Distribusi Frekuensi Disiplin kerja guru (X3)

\begin{tabular}{|c|c|c|c|c|}
\hline \multirow{2}{*}{ No } & Interval Kelas & \multicolumn{3}{|c|}{ Frekuensi } \\
\cline { 3 - 5 } & & Absolut & Relatif (\%) & Kumulatif (\%) \\
\hline 1 & $99-94$ & 7 & 6.67 & 6.67 \\
\hline 2 & $95-99$ & 22 & 20.95 & 27.62 \\
\hline 3 & $100-104$ & 36 & 34.28 & 61.90 \\
\hline 4 & $105-109$ & 18 & 17.15 & 79.05 \\
\hline 5 & $110-114$ & 9 & 8.57 & 87.62 \\
\hline 6 & $115-119$ & 5 & 4.76 & 92.38 \\
\hline 7 & $120-124$ & 3 & 2.86 & 95.24 \\
\hline & $125-129$ & 5 & 4.76 & 100.00 \\
\hline & Jumlah Total & 105 & 100.00 & \\
\hline
\end{tabular}

\section{Uji Persyaratan Analisis}

1. Uji Normalitas

a. Gaya Kepemimpinan transformasional

Tabel 4.12. Tests of Normality

\begin{tabular}{|l|r|r|r|r|r|r|}
\hline & \multicolumn{3}{|c|}{ Kolmogorov-Smirnov $^{\mathrm{a}}$} & \multicolumn{4}{|c|}{ Shapiro-Wilk } \\
\cline { 2 - 7 } & Statistic & \multicolumn{1}{|c|}{ Df } & \multicolumn{1}{c|}{ Sig. } & Statistic & \multicolumn{1}{c|}{ df } & \multicolumn{1}{c|}{ Sig. } \\
\hline $\begin{array}{l}\text { Gaya Kepemimpinan } \\
\text { Transformasional }\end{array}$ & .082 & 105 & .040 & .971 & 105 & .020 \\
\hline
\end{tabular}

b. Motivasi Kerja Guru 
Tabel 4.12. Tests of Normality

\begin{tabular}{|l|r|r|r|r|r|r|}
\hline & \multicolumn{3}{|c|}{ Kolmogorov-Smirnov $^{\mathrm{a}}$} & \multicolumn{3}{|c|}{ Shapiro-Wilk } \\
\cline { 2 - 7 } & Statistic & \multicolumn{1}{c|}{ Df } & \multicolumn{1}{c|}{ Sig. } & Statistic & \multicolumn{1}{c|}{ df } & \multicolumn{1}{c|}{ Sig. } \\
\hline $\begin{array}{l}\text { Gaya Kepemimpinan } \\
\text { Transformasional }\end{array}$ & .082 & 105 & .040 & .971 & 105 & .020 \\
\hline
\end{tabular}

2. Uji Homogenitas

Tabel 4.15. Test of Homogeneity of Variances

\begin{tabular}{|l|r|r|r|r|}
\hline & Levene Statistic & df1 & \multicolumn{1}{|c|}{ df2 } & \multicolumn{1}{|c|}{ Sig. } \\
\hline $\begin{array}{l}\text { Gaya kepemimpinan kepala } \\
\text { sekolah }\end{array}$ & 1.671 & 18 & 67 & .021 \\
Motivasi kerja guru & 1.578 & 18 & 67 & .045 \\
\hline
\end{tabular}

Pengujuan Hipotesis

a. Gaya kepemimpinan transformasional kepala sekolah dengan disiplin kerja

Tabel 4.16. Uji Signifikansi pengaruh gaya kepemimpinan transformasional kepala sekolah dengan disiplin kerja guru

\begin{tabular}{|c|c|c|c|c|c|c|}
\hline \multicolumn{7}{|c|}{ Coefficients ${ }^{a}$} \\
\hline & & \multicolumn{2}{|c|}{ Unstandardized Coefficients } & $\begin{array}{l}\text { Standardized } \\
\text { Coefficients }\end{array}$ & \multirow[b]{2}{*}{$\mathrm{T}$} & \multirow[b]{2}{*}{ Sig. } \\
\hline \multicolumn{2}{|c|}{ Model } & B & Std. Error & Beta & & \\
\hline \multirow[t]{2}{*}{1} & (Constant) & 83.515 & 6.975 & & 11.974 & .000 \\
\hline & Disiplin Kerja & .244 & .067 & .339 & 3.658 & .000 \\
\hline
\end{tabular}

\begin{tabular}{|c|c|c|c|c|c|c|}
\hline \multicolumn{7}{|c|}{ ANOVA $^{\mathrm{B}}$} \\
\hline & & Sum of Squares & Df & Mean Square & $\mathrm{F}$ & Sig. \\
\hline \multirow[t]{3}{*}{1} & Regression & 446.223 & 1 & 446.223 & 13.379 & $.000^{\mathrm{a}}$ \\
\hline & Residual & 3435.434 & 103 & 33.354 & & \\
\hline & Total & 3881.657 & 104 & & & \\
\hline
\end{tabular}

Tabel 4.18. Tingkat hubungan antara gaya kepemimpinan transformasional kepala sekolah dengan disiplin kerja guru

Correlations
\begin{tabular}{|ll|r|r|}
\hline \multicolumn{2}{|c|}{} & VarX1 & \multicolumn{1}{c|}{ VarX3 } \\
\hline VarX1 & Pearson Correlation & 1 & .639 \\
& Sig. (2-tailed) & & .000 \\
& $\mathrm{~N}$ & 105 & 105 \\
\hline $\operatorname{VarX3}$ & Pearson Correlation & .639 & 1 \\
& Sig. (2-tailed) & .000 & \\
$\mathrm{~N}$ & 105 & 105 \\
\hline
\end{tabular}


Tabel 4.19. Hasil perhitungan koefisien korelasi antara gaya kepemimpinan transformasional kepala sekolah dengan disiplin kerja guru

\begin{tabular}{|c|c|c|c|c|}
\hline \multicolumn{5}{|c|}{ Model Summary ${ }^{b}$} \\
\hline Model & $\mathrm{R}$ & R Square & $\begin{array}{l}\text { Adjusted R } \\
\text { Square }\end{array}$ & $\begin{array}{l}\text { Std. Error of the } \\
\text { Estimate }\end{array}$ \\
\hline 1 & $.639^{\mathrm{a}}$ & .408 & .106 & 5.77527 \\
\hline
\end{tabular}

Tabel 4.20. Uji Signifikansi pengaruh gaya kepemimpinan transformasional kepala sekolah dengan motivasi kerja guru

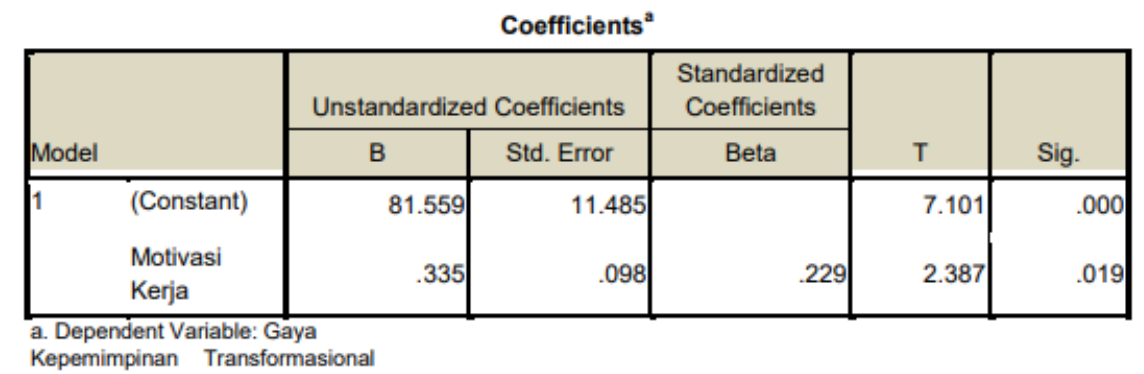

Tabel 4.21. Tabel ANOVA untuk pengujian signifikansi dan linearitas persamaan regresi $\hat{X}_{3}=81.559+0.335 \mathrm{X}_{2}$

\begin{tabular}{|ll|r|r|r|r|r|}
\hline Model & & Sum of Squares & \multicolumn{1}{|c|}{ Df } & Mean Square & F & Sig. \\
\hline 1 & Regression & 203.533 & 1 & 203.533 & 7.700 & $.019^{2}$ \\
& Residual & 3678.124 & 103 & 35.710 & & \\
& Total & 3881.657 & 104 & & & \\
\hline
\end{tabular}

a. Predictors: (Constant), Motivasi Kerja

b. Dependent Variable: Gaya Kepemimpinan

Transformasional

Tabel 4.18. Tingkat hubungan antara gaya kepemimpinan transformasional kepala sekolah dengan disiplin kerja guru

\begin{tabular}{|ll|r|r|}
\hline \multicolumn{3}{|c|}{ Correlations } \\
\hline VarX1 & Pearson Correlation & 1 & .639 \\
& Sig. (2-tailed) & & .000 \\
& $\mathrm{~N}$ & 105 & 105 \\
\hline VarX3 & Pearson Correlation & .639 & 1 \\
& Sig. (2-tailed) & .000 & \\
N & 105 & 105 \\
\hline \multirow{2}{*}{ N. Correlation is significant at the 0.01 level (2-tailed). }
\end{tabular}


Tabel 4.19. Hasil perhitungan koefisien korelasi antara gaya kepemimpinan transformasional kepala sekolah dengan disiplin kerja guru

\begin{tabular}{|c|c|c|c|c|}
\hline \multicolumn{5}{|c|}{ Model Summary ${ }^{b}$} \\
\hline Model & $\mathrm{R}$ & R Square & $\begin{array}{c}\text { Adjusted R } \\
\text { Square }\end{array}$ & $\begin{array}{c}\text { Std. Error of the } \\
\text { Estimate }\end{array}$ \\
\hline 1 & $.639^{\mathrm{a}}$ & .408 & .106 & 5.77527 \\
\hline
\end{tabular}

Tingkat hubungan korelasi parsial

1. Gaya kepemimpinan transformasional kepala sekolah (X1) dengan disiplin kerja guru (X2), dan motivasi kerja di kontrol (X3)

Tabel 4.28. Korelasi parsial $\left(X_{1}\right)$ dan $\left(X_{3}\right),\left(X_{2}\right)$ di kontrol

\begin{tabular}{|c|c|c|c|c|}
\hline \multicolumn{5}{|c|}{ Correlations } \\
\hline \multicolumn{3}{|c|}{ Control Variables } & $\begin{array}{c}\text { Gaya } \\
\text { Kepemimpinan } \\
\text { Transformasional }\end{array}$ & Disiplin Kerja \\
\hline \multirow[t]{2}{*}{$\begin{array}{l}\text { Motivasi } \\
\text { Kerja }\end{array}$} & $\begin{array}{l}\text { Gaya } \\
\text { Kepemimpinan } \\
\text { Transformasional }\end{array}$ & $\begin{array}{l}\text { Correlation } \\
\text { Significance (2-tailed) } \\
\text { Df }\end{array}$ & 1.000 & $\begin{array}{l}.515 \\
.001 \\
102 \\
\end{array}$ \\
\hline & Disiplin Kerja & $\begin{array}{l}\text { Correlation } \\
\text { Significance (2-tailed) } \\
\text { Df }\end{array}$ & $\begin{array}{r}.515 \\
.001 \\
102 \\
\end{array}$ & $\begin{array}{r}1.000 \\
0 \\
\end{array}$ \\
\hline
\end{tabular}

2. Gaya kepemimpinan transformasional kepala sekolah (X1) dengan motivasi kerja guru (X3), dan disiplin kerja di kontrol (X2)

Tabel 4.29. Korelasi parsial $\left(X_{1}\right)$ dan $\left(X_{2}\right),\left(X_{3}\right)$ di kontrol

Correlations

\begin{tabular}{|c|c|c|c|c|}
\hline \multicolumn{3}{|c|}{ Control Variables } & $\begin{array}{l}\text { Motivasi } \\
\text { Kerja }\end{array}$ & $\begin{array}{c}\text { Gaya } \\
\text { Kepemimpinan } \\
\text { Transformasional }\end{array}$ \\
\hline \multirow{6}{*}{\begin{tabular}{|l} 
Disiplin \\
Kerja
\end{tabular}} & Motivasi Kerja & Correlation & 1.000 & .690 \\
\hline & & Significance (2-tailed) & & .004 \\
\hline & & Df & 0 & 102 \\
\hline & Gaya & Correlation & .690 & 1.000 \\
\hline & Kepemimpinan & Significance (2-tailed) & .004 & \\
\hline & Transformasional & Df & 102 & 0 \\
\hline
\end{tabular}

3. Motivasi kerja guru (X1) dengan disiplin kerja guru (X3), dan Gaya kepemimpinan transformasional kepala sekolah (X1) di kontrol 
Tabel 4.30. Korelasi parsial $\left(X_{2}\right)$ dan $\left(X_{3}\right),\left(X_{1}\right)$ di kontrol

\begin{tabular}{|c|c|c|c|c|}
\hline \multicolumn{5}{|c|}{ Correlations } \\
\hline \multicolumn{3}{|c|}{ Control Variables } & Disiplin Kerja & Motivasi Kerja \\
\hline \multirow{6}{*}{$\begin{array}{l}\text { Gaya } \\
\text { Kepemimpinan } \\
\text { Transformasional }\end{array}$} & Disiplin & Correlation & 1.000 & .685 \\
\hline & Kerja & Significance (2-tailed) & & .008 \\
\hline & & Df & 0 & 102 \\
\hline & Motivasi & Correlation & .685 & 1.000 \\
\hline & Kerja & Significance (2-tailed) & .008 & \\
\hline & & Df & 102 & 0 \\
\hline
\end{tabular}

Tabel 4.31. Peringkat kekuatan hubungan antara variabel bebas dengan variabel terikat

\begin{tabular}{|c|c|}
\hline Koefisien korelasi parsial & Peringkat \\
\hline $\mathrm{R}_{\mathrm{y} 12}=0.690$ & Pertama \\
\hline $\mathrm{R}_{\mathrm{y} 23}=0.685$ & Kedua \\
\hline $\mathrm{R}_{\mathrm{y} 13}=0.515$ & Ketiga \\
\hline
\end{tabular}

Tabel 1. Style dan Fungsinya

\begin{tabular}{|c|l|l|}
\hline No & Nama Style & \multicolumn{1}{|c|}{ Fungsi } \\
\hline 1 & JOURNAL_ABSTRACT BODY & Abstrak \\
\hline 2 & JOURNAL_ABSTRACT KEY & Keyword dari abstrak \\
\hline 3 & JOURNAL_AUTHOR & Penulis \\
\hline 4 & JOURNAL_AUTHOR IDENTI & Identitas Penulis \\
\hline 5 & JOURNAL_BODYTE & Teks artikel/paragraf \\
\hline 6 & JOURNAL_FIGURE & Penamaan gambar \\
\hline 7 & JOURNAL_HEADING 1 & Bab (Bold, Kapital Awal) \\
\hline 8 & JOURNAL_HEADING 2 & Sub-bab (Tidak tebal, Kapital Awal) \\
\hline 9 & JOURNAL_HEADING 3 & $\begin{array}{l}\text { Sub-sub-bab (Italic, tidak tebal, } \\
\text { kapital awal) }\end{array}$ \\
\hline 11 & HEPI_REFERENCES & Penulisan daftar Pustaka \\
\hline 12 & HEPI_TABLE & Penamaan tabel \\
\hline 13 & HEPI_TITLE & Judul artikel \\
\hline
\end{tabular}

\section{KESIMPULAN}

Berdasarkan hasil analisis dan pembahasan dapat ditarik kesimpulan sebagai berikut :

1. Dari hasil analisis data ternyata terdapat pengaruh langsung positif dan signifikan terhadap gaya kepemimpinan transformasional kepala sekolah dan disiplin kerja guru MAN di Jakarta Selatan. Dengan hasil yang diperoleh $F$ hitung (13.379) $>F$ tabel (6.93) pada $\alpha=0.05$. Hal ini menunjukkan bahwa model persamaan regresi sangat signifikan. Dan nilai 
hitung korelasi sebesar 0.639 sehingga dapat dinyatakan variabel gaya kepemimpinan transformasional kepala sekolah dan disiplin kerja guru mempunyai korelasi yang cukup kuat. Berdasarkan hasil perhitungan tersebut disimpulkan bahwa gaya kepemimpinan transformasional kepala sekolah dan disiplin kerja guru mempunyai pengaruh yang positif dan signifikan. Dengan demikian maka hipotesis pertama yang menyatakan ada pengaruh yang positif dan signifikan antara gaya kepemimpinan transformasional kepala sekolah dan disiplin kerja guru adalah diterima.

2. Dari hasil analisis data ternyata terdapat pengaruh langsung positif dan signifikan terhadap motivasi kerja guru dan disiplin kerja guru MAN di Jakarta Selatan. Dengan hasil analisis yang diperoleh F hitung (7.700) > F tabel (6.93) pada $\alpha=0.05$. Hal ini menunjukkan bahwa model persamaan regresi sangat signifikan. Dan nilai hitung korelasi sebesar 0.529 sehingga dapat dinyatakan 120 variabel gaya motivasi kerja guru dan disiplin kerja guru mempunyai korelasi yang cukup kuat. Berdasarkan hasil perhitungan tersebut disimpulkan bahwa motivasi kerja guru dan disiplin kerja guru mempunyai pengaruh yang positif dan signifikan. Dengan demikian maka hipotesis kedua yang menyatakan ada pengaruh yang positif dan signifikan antara motivasi kerja guru dan disiplin kerja guru adalah diterima.

3. Dari hasil analisis data ternyata terdapat pengaruh langsung positif dan signifikan terhadap gaya kepemimpinan transformasional kepala sekolah dan motivasi kerja guru MAN di Jakarta Selatan. Dengan hasil analisis yang diperoleh $\mathrm{F}$ hitung (7.567) $>\mathrm{F}$ tabel (6.93) pada $\alpha=0.05$. Hal ini menunjukkan bahwa model persamaan regresi sangat signifikan. Dan nilai hitung korelasi sebesar 0.656 sehingga dapat dinyatakan variabel gaya kepemimpinan transformasional kepala sekolah dan motivasi kerja guru mempunyai korelasi yang cukup kuat. Berdasarkan hasil perhitungan tersebut disimpulkan bahwa gaya kepemimpinan transformasional kepala sekolah dan motivasi kerja guru mempunyai pengaruh yang positif dan signifikan. Dengan demikian maka hipotesis ketiga yang menyatakan ada pengaruh yang positif dan signifikan antara gaya kepemimpinan transformasional kepala sekolah dan motivasi kerja guru adalah diterima.

4. Pengaruh antara gaya kepemimpinan transformasional kepala sekolah dan motivasi kerja guru terhadap disiplin kerja guru MAN di Jakarta Selatan memiliki tingkat signifikansi cukup tinggi.

\section{Saran}

Dengan mengetahui adanya pengaruh yang positif antara gaya kepemimpinan transformasional kepala sekolah dan motivasi kerja terhadap disiplin kerja guru, maka :

1. Gaya kepemimpinan transformasional kepala sekolah di MAN Jakarta Selatan berada pada kategori baik. Sejalan dengan semakin meningkatnya tuntutan masyarakat terhadap disiplin kerja guru maka penerapan gaya kepemimpinan transformasional kepala sekolah harus lebih efektif. Untuk itu kepala sekolah perlu mengikuti workshop manajemen serta lebih terbuka pada saran dan kritik yang sifatnya membangun dari semua pihak.

2. Berdasarkan pengolahan data, motivasi kerja guru termasuk pada kategori cukup baik. Motivasi kerja guru perlu ditingkatkan terutama 
motivasi eksternal. Hal ini dapat dilakukan oleh kepala sekolah dengan cara peningkatan kesejahteraan guru, menjalin hubungan interpersonal yang lebih harmonis dan peningkatan kualitas lingkungan kerja yang aman dan nyaman 124 sehingga para guru dapat meraih prestasi kerja yang lebih baik pada waktu mendatang.

3. Berdasarkan pengolahan data, disiplin kerja guru juga termasuk pada kategori cukup baik. Sejalan dengan tuntutan masyarakat terhadap peningkatan kualitas sekolah, perlu ditingkatkan kedisiplinan kerja guru dengan pembinaan dan pengawasan yang lebih intensif dari kepala sekolah.

4. Perlu diperhatikan hal-hal yang memberikan kontribusi terhadap peningkatan disiplin kerja guru. Untuk peningkatan disiplin kerja guru maka kepala sekolah semestinya dapat menentukan strategi yang efektif dan apabila terjadi penurunan kualitas disiplin kerja maka dapat mengidentifikasi penyebabnya sedini mungkin.

5. Penerapan gaya kepemimpinan kepala sekolah di MAN Jakarta Selatan pada umumnya sudah baik. Agar lebih baik lagi perlu mengoptimalkan manajemen dan supervisi terhadap disiplin kerja guru dalam pelaksanaan proses pembelajaran di kelas. Hal ini dapat meningkatkan kompetensi guru dan mutu pendidikan.

6. Untuk meningkatkan motivasi kerja guru sebaiknya kepala sekolah memberikan kebijakan yang dapat memotivasi guru agar melakukan hasil kerja terbaik, seperti memberikan apresiasi terhadap guru berprestasi dan memberikan kesempatan kepada guru seluas-luasnya untuk lebih mengembangkan potensi yang ia miliki.

7. Untuk meningkatkan disiplin kerja guru sebaiknya kepala sekolah meningkatkan sistem pembinaan dan pengawasan. Sistem pembinaan yang 125 dilaksanakan hendaknya bervariasi misalnya dengan menggunakan metode ESQ. Sistem pengawasan dapat ditingkatkan dengan menggunakan kemajuan sistem informasi untuk memantau kehadiran guru di sekolah maupun di kelas.

\section{DAFTAR PUSTAKA}

Ardi, Romli. 2002. Hand Out Kepemimpinan Pendidikan. Jakarta: PPS UHAMKA

Arikunto, Suharsimi. 1998. Prosedur Penelitian Suatu Pendekatan Praktek. Jakarta: Rineka Cipta.

Azwar, S. 2001. Reliability dan Validitas. Yogyakarta : Pustaka Pelajar

Baltus, Rita K. 1983. Personal Psychology for Life and work.New York: McGraw-Hill Book Company.

Baron A. Robert, Greenberg Jerald. Behavior in Organization Understanding and Managing The Human Side of Work. New Jersey: Prentice-Hall, Inc.

Blanchard, K. Hersey, P. 1992. Manajemen Perilaku Organisasi: Pendayagunaan Sumber Daya Manusia. (terjemahan: Agus Dharma). Jakarta: Erlangga.

Djamarah, Syaiful B. 2002. Psikologi Belajar. Jakarta: Rineka Cipta.

Fattah, Nanang. 2001. Landasan Manajemen Pendidikan. Bandung: Remaja Rosdakarya. 
Feldman, Robert S. 1987. Understanding Psychology.New York: McGraww-Hill

Fiedler, Fred E. and Charmers, Martin M. 1974. Leadership and Effective Management. Glenview Illionis: Scott, Foresmen and Company.

Gardner, W. John. 1990. On Leadhership. New York : The Free Press.

Gerungan. W.A.1991. Psikologi Sosial. Bandung: Eresco.

Gordon R. Judith. Organization Behaviour A Diagnostic Approach. New Jersey: Prentice-Hall.

Lubis, Hadi, Satria. 2009. Total Motivation. Yogyakarta: Proyou.

Harahap, Baharuddin. 1983. Supervisi Pendidikan Yang Dilaksanakan Oleh Guru, Kepala Sekolah, Penilikdan Pengawas Sekolah. Jakarta: Damai Jaya.

Hasibuan, J.J. 1986. Proses Belajar Mengajar. Bandung : Remaja Karya.

Hollenbeck. R. John, Wagner. 1995. Managemen of Organizational Behaviour New Jersey: Prentice-Hall, Inc.

Ibrahim, R. 2002. KurikulumPembelajaran.Bandung: Jurusan Kurikulum dan Teknologi Pendidikan FIB UPI.

Idris, Zahara. 1981. Dasar-dasar Kependidikan. Padang : Angkasa Raya.

Kartono, Kartini. 1992. Pemimpin dan Kepemimpinan, Jakarta : Rajawali

2005. Kepemimpinan: Apakah Kepemimpinan Abnormal itu?. Jakarta: PT. Grafindo Persada.

Keeting, Charles J. 1986. Kepemimpinan: Teori dan Pengembangannya. (terjemahan oleh Handayana). Yogyakarta: Kanisius.

Lipham, James M. 1985.The Principal Conceps, Competencies, and Cases. New York: Longman Inc.

Djokosantoso, Moelyono. 2008. More About Beyond Leadership. Jakarta: PT. Elex Media Komputindo.

Morgan, Clifford T. et al. 1986 Introduction to Psychology.New York: McGrawHill.

Muwarni, R. Santosa. 2001. Statistika Terapan: Teknik Analisis Data. Diklat Mata Kuliah Program Pasca Sarjana UHAMKA Jakarta.

Nugroho, B.A. 2005. Strategi Jitu Memilih Metode Statistik Penelitian dengan SPSS. Yogyakarta: Andi Offset.

Oppenheim, A.N. 1966. Questionare Design and Attitude Measurement.New York: Basic Books Inc.

Papalia, Diane E. and Oldes, Sally Wendkos. 1985. Psychology. New York:McGraw- Hall Inc.

Pasolong, Harbani. 2008. Kepemimpinan Birokrasi. Bandung : Alfabeta

Robbins, Stephen P. 1996.Perilaku Organisasi. Terjemah oleh Benyamin Molan Jakarta: PT. Raja Grafindo.

Rohaety, E ; Tresnati, R. \& Latief, M. 2009. Metodologi Penelitian Bisnis Dengan Aplikasi SPSS.Jakarta: Mitra Wacana Media.

Rokeah, Milton. 1976. Belief Attitudes and Values. San Francisco: Jossey-Bass Publisher. 
Rue, W Leslie \& Byars L, Lioyd. 1996. Supervision Key Link to Producvity :FiftyEdiontion, New York : Irwin.

Sallis, Edward. 1993. Total Quality in Education. London : Kogan Page Educational Management Series.

Samana, A. 1994.Profesionalisme Keguruan.Yogyakarta : Kanisius.

Sarwono, Jonathan. (2006). Analisis Data Penelitian Menggunakan SPSS 13. Yogyakarta : Penerbit ANDI.

Sears, David O., Freedman, Jonathan L., and Peplau, L. Anne. 1992. Psikologi Sosial. Terjemah oleh Agus Mulyana. Jakarta : Erlangga.

Soekarso. Agus Sosro. Iskandar Putong. Cecep Hidayat. 2010. Teori Kepemimpinan. Jakarta : Mitra Wacana Media.

Stoner, Jamer A.F. and Sindoro A. 1996.Manajemen.Jakarta : PT. Indeks Gramedia Group.

Sundriamunawar, Haryono. 2006. KepemimpinanPeran Serta dan Produktivitas.Bandung : Mandar Maju.

Sugiyono. 2000. Statistika Untuk Penelitian. Bandung : Alfabeta.

2001. Metode Penelitian Bisnis. Bandung : Alfabeta.

.2006. Metode Penelitian Pendidikan : Pendekatan Kuantitatif, kualitatif, dan Pendekatan $R$ \& D. Bandung : Alfabeta.

Suradinata, Ermaya. 1979. Psikologi Kepegawaian. Bandung : Ramandan.

Suryadi, Ace dan Mulyana, Wiana.1993.Kerangka Konseptual Mutu Pendidikan dan Pembinaan Kemampuan Profesional Guru.Jakarta : Cardimas Metropole.

Sutisna, Oteng. 1985. Administrasi Pendidikan: Dasar Teoritis Untuk Praktek Profesional. Bandung: Angkasa.

Sutrisno, Edy. 2010. Manajemen Sumber Daya Manusia. Jakarta: Kencana.

Syah, Muhibbin. 2000. Psikologi Pendidikan dengan Pendekatan Baru.Bandung: Remaja Rosdakarya.

Tim Dosen FIP-IKIP Malang.1980.Pengantar Dasar-Dasar Kependidikan. Surabaya: Usaha Nasional.

Toha, Miftah. 2004. Kepemimpinan Dalam Manajemen (suatu pendekatan perilaku). Jakarta: PT. Raja Grapindo Persada. . 2007. Perilaku Organisasi: Konsep Dasar dan Aplikasinya. Jakarta: Raja Grafindo

Persada.

Timpe, A. Dale. 1998. The Art and Science of Business Management Performace. New York : KEND Publishing. Inc.

Tjiptono, Fendy. 1996. Manajemen Jasa. Yogyakarta : Andi.

Tracey, William R. 1974. Managing Training and Development System.New York: AMACOM.

Uno, Hamzah. 2010. Teori Motivasi \& Pengukurannya.Jakarta: Bumi Aksara.

Usman, Husaini. 2006. Manajemen: Teori Praktek dan Riset Pendidikan. Jakarta : Bumi Aksara.

Wahjosumidjo.2002.Kepemimpinan Kepala Sekolah, Tinjauan Teoritik dan Permasalahannya.Jakarta: PT. Raja Grafindo Persada. 
Walgito, Bimo. 2001. Psikologi Sosial. Yogyakarta: Penerbit Andi.

Wirawan. 2002. Kapita Selekta Teori Kepemimpinan: Pengantar Untuk Praktek dan Penelitian. Jakarta: Yayasan Bangun Indonesia \& UHAMKA Press.

Yukl, Gary A. 2001. Leadership In Organization. New York: Prentice-Hall Inc.

Yutmini, Sri. 1992. Strategi Belajar Mengajar. Surakarta: FKIP UNS 